C. Biotyping coagulase-negative staphylococci. J Clin Microbiol 1988;26:1950-6.

6. Parisi JT. Hecht DW. Plasmid profiles in epidemiologic studies of infections by Staphplococcus epidermidis. J Infect Dis 1980;141:637-43.

7. Hartstein AI, Valvano MA, Morthland VH, Fuchs PC, Potter SA, Crosa JH. Antimicrobic susceptibility and plasmid profile analysis as identity tests for multiple blood isolates of coagulase-negative staphylococci. J Clin Microbiol 1987;25:589-93.

8. Renaud F, Frenez J, Etienne J, et al. Restriction endonuclease analysis of Siaphylococcus epidermidis DNA may be a useful epidemiological marker. J Clin Microbiol 1988;26:1729-34.

9. Selander RK, Caugant DA, Ochman H. Musser JM, Gilmour MN, Whittam TS. Methods of multilocus enzyme electrophoresis for bacterial population genetics and systemics. Appl Environ Microbiol 1986:51:873-84.

10. Goldmann DA, Pier GB. Pathogenesis of infections related to intravascular catheterization. Clin Microbiol Rev 1993;6:176-92.
11. Sitges-Serra A, Puig P, Linares J, et al. Hub colonization as the initial step in an outbreak of catheter-related sepsis due to coagulase-negative staphylococci during parenteral nutrition. J Parenter Enter Nutr 1984:8:668-72.

12. Salzman MB, Isenberg HD, Shapiro JF, Lipsitz PJ, Rubin LG. A prospective study of the catheter hub as the portal of entry for microorganisms causing catheter-related sepsis in neonates. $J$ Infect Dis 1993; 167:487-90.

13. Selander RK. Musser JM. Population genetics of bacterial pathogenesis. In: Iglewski BH, Clark VL, eds. Molecular basis of bacterial pathogenesis. San Diego: Academic Press, 1990: 1 1-36.

14. Musser JM, Barenkamp SJ, Granoff DM, Selander RK. Genetic relationships of serologically nontypable and serotype b strains of Haemophilus infuenzae. Infect Immun 1986;52:183-91.

15. Pfaller MA, Herwaldt LA. Laboratory, clinical, and epidemiological aspects of coagulase-negative staphylococci. Clin Microbiol Rev 1988:1:281-99.

\title{
Role of Amoxicillin Serum Levels for Successful Prophylaxis of Experimental Endocarditis Due to Tolerant Streptococci
}

\author{
U. Fluckiger, P. Francioli, J. Blaser, M. P. Glauser, \\ and Ph. Moreillon
}

\author{
Division of Infectious Diseases, Department of Internal Medicine, Centre \\ Hospitalier Universitaire Vaudois, Lausanne, and Department of \\ Medicine, University Hospital, Zurich. Switzerland
}

\begin{abstract}
The importance of amoxicillin serum profiles for successful prophylaxis of experimental endocarditis in rats was assessed. Animals with catheter-induced vegetations were challenged intravenously with large inocula of Streptococcus sanguis and received one of the following amoxicillin dosages: single or multiple bolus injection of $40 \mathrm{mg} / \mathrm{kg} ; 40 \mathrm{mg} / \mathrm{kg}$ administered as a continuous infusion over $12 \mathrm{~h}$; or either 9 or $18 \mathrm{mg} / \mathrm{kg}$ administered over 12 or $24 \mathrm{~h}$, respectively. The regimen producing a single transient high peak serum level failed to prevent experimental endocarditis; in contrast, a second injection $6 \mathrm{~h}$ after the first resulted in successful prophylaxis. Likewise, the three regimens of continuous, relatively low-dose regimens prevented infections. Thus, the most important parameter for successful prophylaxis was the duration of inhibitory concentration of the drug in the serum. The total dose of antibiotic, the peak serum levels, or the area-under-the-curve values were not predictive of successful prophylaxis.
\end{abstract}

To prevent streptococcal endocarditis in patients undergoing medical or surgical procedures that put them at risk for bacteremia, high and sometimes repeated doses of antibiotics are recommended [ 1,2$]$. This strategy has been largely based on results of animal studies showing that high and prolonged levels of bactericidal antibiotics (given before or shortly after

Received 3 May 1993; revised 21 January 1994.

Presented in part: 31 st Interscience Conference on Antimicrobial Agents and Chemotherapy, Chicago, 29 September to 2 October 1991 (abstract $358)$.

Grant support: Swiss National Foundation for Scientific Research (3-8640.86 ).

Reprints or correspondence: Dr. P. Francioli, Division of Infectious Diseases, Dept. of Internal Medicine, Centre Hospitalier Universitaire Vaudois, 1011 Lausanne. Switzerland.

The Journal of Infectious Diseases 1994;169:1397-400 (C) 1994 by The University of Chicago. All rights reserved. 0022-1899/94/6906-0037\$01.00 intravenous [iv] bacterial challenge) were necessary to provide optimal protection against streptococcal endocarditis in rabbits and rats $[3,4]$.

However, while experimental evidence has demonstrated that prolonged antibiotic serum levels were more effective than short-course prophylaxis [3], the importance of drug serum levels per se for successful protection has not been thoroughly investigated. In fact, while large doses of antibiotics are recommended for prophylaxis, several lines of evidence suggest that high drug concentrations might not be a prerequisite for successful protection. First, many antibiotics do not gain efficacy in a dose-dependent manner once above the MIC. For example, the optimal bactericidal concentration of penicillins in vitro (the most frequently recommended drugs for prophylaxis) is usually not much higher than their MICs [5]. Moreover, paradoxically low bacterial killing has been described at high concentrations of such anti- 
biotics [6]. Second, studies have shown that multiple doses of penicillin $\mathrm{V}$, which produced prolonged but relatively low serum levels of antibiotic, successfully prevented endocarditis in rabbits challenged with large bacterial inocula (i.e., $10^{8}$ cfu) [7]. Therefore, the high blood concentrations of antibiotics resulting from most prophylactic regimens in humans may not be required for successful protection but merely ensure more prolonged serum levels.

In the present experiments, we investigated the importance of serum levels of amoxicillin for successful prophylaxis of experimental endocarditis in rats challenged with a large inoculum of Streptococcus sanguis.

\section{Materials and Methods}

Bacterial strain and antibiotic susceptibility. A previously described strain of Streptococcus sanguis was used [8]. The MIC and $\mathrm{MBC}$ values of amoxicillin for this strain were $0.032 \mathrm{mg} / \mathrm{L}$ and $>128 \mathrm{mg} / \mathrm{L}$, respectively. Thus, the test organism was "tolerant" to amoxicillin as defined by an MBC to MIC ratio $>32$ and by an ability to survive amoxicillin treatment in time-kill curves in vitro [8].

Serum inhibitory and bactericidal titers. Serum inhibitory and bactericidal titers of amoxicillin were measured as previously described [3] in groups of 9 rats, either after a single iv bolus of $40 \mathrm{mg} / \mathrm{kg}$ amoxicillin (at $30 \mathrm{~min}$ and 2 and $6 \mathrm{~h}$ ) or after continuous infusion of the drug (at $1,3,6,8,12$, and $14 \mathrm{~h}$ ). Organisms were subcultured on penicillinase-containing blood agar $\left(5 \times 10^{6} \mathrm{IU} / \mathrm{L}\right.$; Bactopenase; Difco, Detroit). The serum inhibitory titer was the highest dilution of serum inhibiting visible bacterial growth, and the serum bactericidal titer was the highest dilution of serum providing $99.9 \%$ killing of the original inoculum after incubation for $18 \mathrm{~h}$.

Serum levels of amoxicillin. Serum levels of amoxicillin were determined in groups of 3-6 rats several times during and after antibiotic administration. Antibiotic concentrations were measured by the agar diffusion method using Bacillus subtilis ATCC 6633 [9]. For standard curves, amoxicillin was diluted in pooled rat serum. The limit of detection of the bioassay was $0.6 \mathrm{mg} / \mathrm{L}$.

Production of endocarditis and installation of the infusionpump device. Female Wistar rats $(180-200 \mathrm{~g})$ were used. As previously described $[3,8]$, a polyethylene catheter was placed through the right carotid artery across the aortic valve and secured with a silk ligature. At the same time, a sterile silastic catheter (Dow Chemical, Midland, MI) was inserted through the jugular vein into the superior vena cava. The line was tunneled subcutaneously and brought to the skin of the interscapular region. The external portion of this cannula was connected to a programmable infusion pump (pump 44; Harvard Apparatus, South Natick, MA) through a flow-through swivel, which permitted the animal to move in the cage [10]. Bacterial endocarditis was induced $24 \mathrm{~h}$ after catheterization by iv challenge with various sizes of bacterial inocula.

Efficacy of various doses of amoxicillin administered either as an iv bolus or continuous infusion. Rats were challenged with $\sim 100$ times the $I_{90}$ of $S$. sanguis $\left(10^{7-8} \mathrm{cfu}\right)$. To ensure that infected rats were exposed to a precise amount of drug, antibi- otic prophylaxis was started immediately after iv bacterial challenge. Despite the fact that this setting does not exactly mimic antibiotic prophylaxis in humans (who are given prophylaxis prior to procedures that could cause bacteremia), such postchallenge prophylaxis has proved to be as effective as standard prechallenge administration of amoxicillin in experimental endocarditis [11]. Moreover, there is ample evidence in both animals and humans to suggest that prophylactic antibiotics operate essentially after, not before, transient bacteremia induced by procedures such as dental extractions (in animals and humans [12]) or after iv bacterial challenge (in animals [3]). We used the following amoxicillin regimens: single or multiple bolus injection of $40 \mathrm{mg} / \mathrm{kg}$, a total of $40 \mathrm{mg} / \mathrm{kg}$ stowly infused over $12 \mathrm{~h}$ (by infusion pump), $9 \mathrm{mg} / \mathrm{kg}$ administered by continuous infusion over $12 \mathrm{~h}$, and $18 \mathrm{mg} / \mathrm{kg}$ administered over $24 \mathrm{~h}$. Controls received saline.

Evaluation of prophylaxis. Animals were killed $48-72 \mathrm{~h}$ after bacterial challenge. Aortic vegetations were excised, weighed, homogenized in $1 \mathrm{~mL}$ of saline, serially diluted, and plated on penicillinase-containing blood agar plates. The number of viable bacteria was counted after $48 \mathrm{~h}$ of incubation at $37^{\circ} \mathrm{C}$, and the results were expressed in $\log _{10} \mathrm{cfu} / \mathrm{g}$ of vegetation. The dilution technique permitted the detection of $\geqslant 10^{2} \mathrm{cfu} / \mathrm{g}$ of vegetation.

Pharmacokinetic parameters and statistical analysis. The area-under-the-curve (AUC) values were calculated by the log trapezoid method [13]. The $\chi^{2}$ test with Yates's correction was used for statistical comparison.

\section{Results}

Efficacy of a fixed dose of amoxicillin administered either as an iv bolus or continuous infusion. To delineate which parameters were important in preventing endocarditis, experiments were designed to analyze the role of the peak serum level, the total dose of antibiotic, the AUC values of antibiotic serum levels, and the duration of inhibitory drug serum levels after bacterial challenge. The serum kinetics produced by the various antibiotic regimens (figure $1 \mathrm{~A}$ ) and the resulting serum inhibitory titers (figure $1 \mathrm{~B}$ ) are shown. A single bolus injection of $40 \mathrm{mg} / \mathrm{kg}$ amoxicillin (curve a) generated high peak serum levels $(75 \mathrm{mg} / \mathrm{L})$ that were $\geqslant 2000$ times the MIC of amoxicillin for $S$. sanguis and high AUC values $(60$ $\mathrm{mg} / \mathrm{L} \cdot \mathrm{h}$ ) but a relatively short duration in serum of the drug $(\leqslant 6 \mathrm{~h})$, as shown by serum drug levels and inhibitory titers. Of note, no serum bactericidal titers were detected at any time. In comparison, continuous infusion (curve b) produced substantially lower drug serum levels $(3 \mathrm{mg} / \mathrm{L})$ and AUC values $(20 \mathrm{mg} / \mathrm{L} \cdot \mathrm{h})$ but longer duration in serum of the drug $(\geqslant 12 \mathrm{~h})$.

In vivo, these two regimens showed different efficacies. Figure 2 shows that iv bolus (column a) did not protect rats challenged with 100 times the $\mathrm{ID}_{90}$ of $S$. sanguis. In contrast, however, $12 \mathrm{~h}$ of continuous infusion protected rats challenged with the large inoculum (column b) even though it 

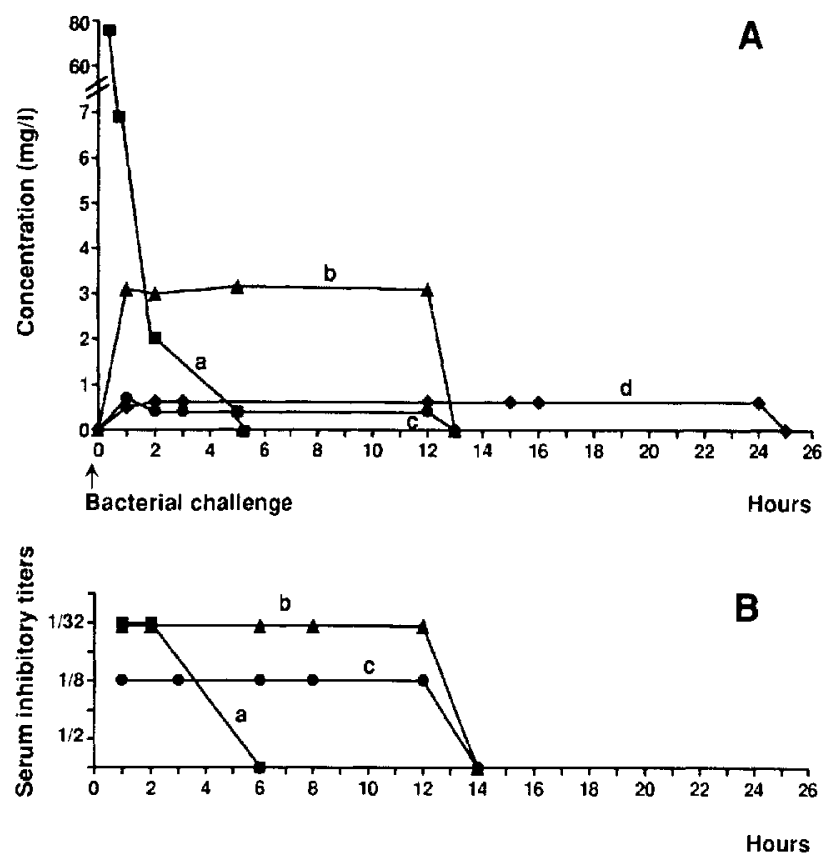

Figure 1. Amoxicillin serum levels (A) and serum inhibitory titers $(\mathbf{B})$ produced by various antibiotic regimens in rats: $a$, single bolus injection, $40 \mathrm{mg} / \mathrm{kg}$; b, continuous infusion of $40 \mathrm{mg} / \mathrm{kg}$ over $12 \mathrm{~h}$; $\mathrm{c}$, continuous infusion of $9 \mathrm{mg} / \mathrm{kg}$ over $12 \mathrm{~h}$; and d, continuous infusion of $18 \mathrm{mg} / \mathrm{kg}$ over $24 \mathrm{~h}$. No serum bactericidal titers were detected at any time or at any dosage.

produced substantially lower drug levels and AUC values than did iv bolus. Thus, in this setting, the total dose of antibiotic, the peak serum levels, or AUC values were not predictive of successful prophylaxis. The most important parameter appeared to be the duration of detectable antibiotic serum levels after bacterial challenge. To test whether these observations might be confirmed under more stringent conditions, additional experiments were done using a dose of amoxicillin that was two to four times lower.

Prophylaxis with prolonged low-dose amoxicillin. Compared with the iv bolus regimen (figure 1, curve a), infusion of $9 \mathrm{mg} / \mathrm{kg}$ amoxicillin over $12 \mathrm{~h}$ (curve c) or $18 \mathrm{mg} / \mathrm{kg}$ over $24 \mathrm{~h}$ (curve d) produced serum levels that were $>100$ times lower (0.6 vs. $75 \mathrm{mg} / \mathrm{L}$ compared with iv bolus) and AUC values that were $5-10$ times lower $(6-12$ vs. $60 \mathrm{mg} / \mathrm{L} \cdot \mathrm{h})$ but substantially longer detectable serum drug levels and inhibitory titers. As a result, prophylaxis with both low-dose regimens successfully prevented endocarditis in rats challenged with 100 times the $\mathrm{ID}_{90}$ of $S$. sanguis (figure 2 , columns $c$ and d) whereas iv bolus did not (column a).

Efficacy of a single bolus of amoxicillin versus two doses injected at a 6 - $h$ interval. Since a single bolus injection of amoxicillin produced only a transient drug level in serum of $\leqslant 6 \mathrm{~h}$, we tested whether prolonging this drug level by a second dose of $40 \mathrm{mg} / \mathrm{kg}$ antibiotic given $6 \mathrm{~h}$ later might restore successful prophylaxis. As expected, injection of this second dose restored successful prophylaxis (figure 2, column e).

\section{Discussion}

These results demonstrate that the most important feature underlying successful amoxicillin prophylaxis against tolerant streptococcal endocarditis was the duration of antibiotic serum inhibitory titers after bacterial challenge. Successful prophylaxis against this organism did not require high peak serum levels of antibiotics, as often advocated for antibiotic prophylaxis against endocarditis in humans [ 1,2$]$. Indeed, in our experiments, high peak serum levels produced by a single iv bolus of $40 \mathrm{mg} / \mathrm{kg}$ amoxicillin (as often used in antibiotic prophylaxis experiments $[3,8]$ ) failed to prevent endocarditis due to large bacterial inocula, despite peak serum concentrations of antibiotics that were $\geqslant 2000$ times greater than the MIC for the test organism and of serum inhibitory titers that were detectable for almost $6 \mathrm{~h}$. In contrast, drug serum levels that were 20 times lower main tained by continuous injection for $\geqslant 12$ h effectively protected the animals despite AUC values that were 60 times lower than after the iv bolus regimen. Thus, the only relevant parameter that reliably predicted successful prophylaxis was the duration of serum inhibitory activity after bacterial challenge. The total antibiotic dose, peak serum levels, or AUC values did not correlate with protection of the animals.

In these experiments, antibiotic serum levels producing inhibitory titers as low as $1 / 8$ successfully prevented experimental endocarditis. Whether even lower levels would also be protective is not known. However, no serum bactericidal activity was detected against this tolerant streptococcal strain at any time or at any antibiotic dosage. Thus, successful pro-

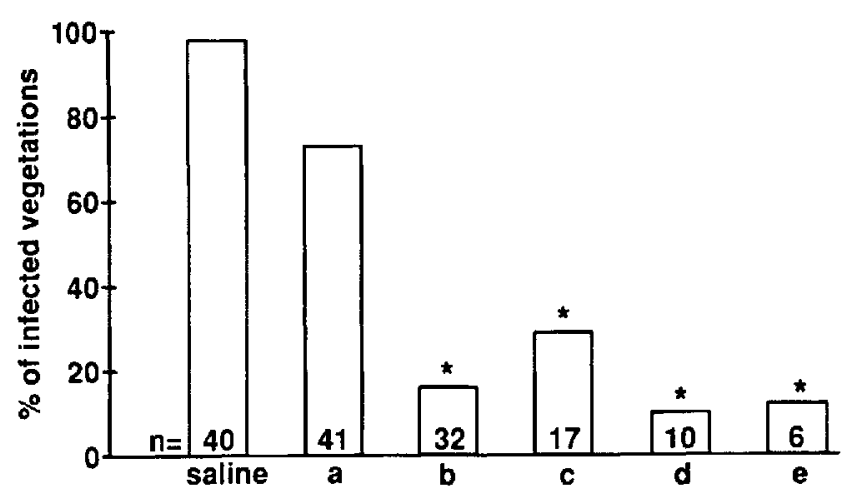

Figure 2. Prophylaxis of experimental endocarditis with amoxicillin given as intravenous (iv) bolus or prolonged ( 12 or $24 \mathrm{~h}$ ) infusion. Rats were challenged with $\sim 100$ times the $\mathrm{ID}_{90}$ of Streptococcus sanguis. Prophylaxis was started immediately after challenge. Treatment groups received a, iv bolus, $40 \mathrm{mg}$ of amoxicillin/ $\mathrm{kg}$; b, continuous 12-h infusion of $40 \mathrm{mg} / \mathrm{kg}$; c, continuous $12-\mathrm{h}$ infusion of $9 \mathrm{mg} / \mathrm{kg}$; $\mathrm{d}$, continuous $24-\mathrm{h}$ infusion of $18 \mathrm{mg} / \mathrm{kg}$; and e, 2 consecutive iv bolus infections of $40 \mathrm{mg} / \mathrm{kg}$ at 6 -h intervals. Number of animals per group are indicated at bottom of columns. ${ }^{*} P<.05$ compared with animals injected with saline or single bolus of antibiotic (a). 
phylaxis was unlikely to be mediated by mere antibiotic-induced killing. In such nonkilling conditions, the exact mechanism underlying successful prophylaxis remains speculative. One hypothesis suggests that prolonged inhibition of bacterial growth by nonkilling antibiotics may allow enough time for alternative host defense mechanism(s), such as platelet microbicidal protein(s) [14], to clear bacteria from the vegetations. If true, such mechanism(s) would be of major importance for prophylaxis, and presumably also therapy, of endocarditis due to tolerant (and maybe also nontolerant) streptococci. This may be particularly relevant because up to $80 \%$ of streptococci isolated from patients with endocarditis may be tolerant to $\beta$-lactam antibiotics and other cell wall inhibitors [5]. Moreover, since prolonged low-dose prophylaxis protected animals challenged with a highly amoxicillintolerant streptococcal strain, it is likely that such a regimen would also protect rats inoculated with nontolerant (kill-sensitive) streptococci.

Although the results of animal experiments cannot be applied directly to humans, the present observation bears some practical implications. First, the results strongly support the current recommendations of the American Heart Association, which advocates two successive doses of amoxicillin (3 $\mathrm{g}$ and $1.5 \mathrm{~g} 6 \mathrm{~h}$ later) as oral prophylaxis for dental procedures [1]. Such a regimen provides antibiotic coverage for $>10 \mathrm{~h}$, a period that appeared optimal in our setting. Moreover, administration of two consecutive doses of antibiotics may also find some support in our results with repeated (two dose) iv bolus regimen: Injection of a second iv bolus of amoxicillin $6 \mathrm{~h}$ after the first restored successful prophylaxis, presumably by prolonging the overall duration of serum inhibitory titers from $\leqslant 6 \mathrm{~h}$ (after a single bolus) to $\sim 12 \mathrm{~h}$.

Second, our observations raise the question of prolonged low-dose prophylaxis for humans. Such a regimen might avoid the side effects linked to high doses of oral antibiotics. Prolonged low-dose prophylaxis may be particularly convenient by using antibiotics with long serum half-lives in humans. However, a low-dose regimen in humans must be handled with caution, because prophylaxis failure has been described after prolonged courses of relatively low doses of antibiotics without an initial loading dose [15]. Therefore, further studies of prolonged low-dose prophylaxis are warranted.

\section{Acknowledgments}

We thank M. Giddey and M. Knaup for excellent technical work.

\section{References}

1. Dajani AS, Bisno LA, Chung DT, et al. Prevention of bacterial endocarditis. Recommendations by the American Heart Association. JAMA 1990;246:2919-22.

2. Simmons NA. Antibiotic prophylaxis of infective endocarditis. Recommendations from the Endocarditis Working Party of the British Society for Antimicrobial Chemotherapy. Lancet 1990;335:88-93.

3. Moreillon P, Francioli P, Overholser D, Meylan P, Glauser MP. Mechanisms of successful amoxicillin prophylaxis of experimental endocarditis due to Streptococcus intermedius. J Infect Dis 1986;154:801-7.

4. Durack DT, Petersdorf RG. Chemotherapy of experimental streptococcal endocarditis. 1. Comparison of commonly recommended prophylactic regimens. J Clin Invest 1973;52:592-8.

5. Meylan PR. Francioli P. Glauser MP. Discrepancies between MBC and actual killing of viridans group streptococci by cell-wall-active antibiotics. Antimicrob Agents Chemother 1986;29:418-23.

6. Eagle $H$, Musselman AD. The rate of bactericidal action of penicillin in vitro as a function of its concentration and its paradoxically reduced activity at high concentration against certain organisms. J Exp Med 1948;88:99-131.

7. Pelletier LL Jr. Durack DT, Petersdorf RG. Chemotherapy of experimental streptococcal endocarditis. IV. Further observation on prophylaxis. J Clin Invest 1975;56:319-30.

8. Glauser MP, Bernard JP, Moreillon P. Francioli P. Successful singledose amoxicillin prophylaxis against experimental endocarditis: evidence for two mechanisms of protection. J Infect Dis 1983;147:56875.

9. Anhalt JP. Assays for antimicrobial agents in body fluid. In: Balows A. Hausler WJ Jr. Isenberg HD. Shadomy HJ, eds. Manual of clinical microbiology. 5th ed. Washington, DC: American Society for Microbiology, 1991: 1105-16.

10. Thauvin C. Eliopoulos GM. Willey S, Wennerstein CH, Moellering RC Jr. Continuous-infusion ampicillin therapy of enterococcal endocarditis in rats. Antimicrob Agents Chemother 1987;31:139-43.

11. Berney P. Francioli P. Successful prophylaxis of experimental streptococcal endocarditis with single-dose amoxicillin administered after bacterial challenge. J Infect Dis 1990:161:281-5.

12. Hall G, Hedström SA. Heimdahl A. Nord CE. Prophylactic administration of penicillins for endocarditis does not reduce the incidence of postextraction bacteremia. Clin Infect Dis 1993;17:188-94.

13. Gibaldi M. Perrier D. Pharmacokinetics. 2nd ed. New York: Marcel Dekker, 1982:449.

14. Yeaman MR. Norman DC, Bayer AS. Platelet microbicidal protein enhances antibiotic-induced killing of and postantibiotic effect in Staplylococcus aurets. Antimicrob Agents Chemother 1992;36: $1665-70$.

15. Durack DT. Kaplan EL. Bisno AL. Apparent failures of endocarditis prophylaxis. Analysis of 52 cases submitted to a national registry. JAMA 1983;250:2318-22. 